\title{
What is the Connection of Blood Group with Lady Finger
}

\section{Likeliness?}

\section{Imran Qadir M and Muneer $\mathrm{N}^{*}$ \\ Institute of Molecular Biology and Biotechnology, Bahauddin Zakariya University, Pakistan}

*Corresponding author: Nazia muneer, Institute of Molecular Biology and Biotechnology, Bahauddin Zakariya University, Multan, Pakistan, Email:

\section{Research Article}

Volume 4 Issue 1

Received Date: January 8, 2019

Published Date: February 11, 2019

DOI: $10.23880 /$ oajmb-16000138 naziamuneer360@gmail.com

\section{Abstract}

Objective of present study was to correlate blood grouping with lady finger likeliness. 173 students were participated in the project studies who were students in Bahauddin Zakariya University, Multan, Pakistan. We observed blood group of different subjects and enlisted them according to their blood group connection with lady finger likeliness. During the sampling of subject, we asked them a question about our projects that are they like lady finger or not? It is concluded from the present study that $\mathrm{B}+$ like the lady finger most and $\mathrm{AB}$ - like the lady finger least.

Keywords: Blood Group; Lady Finger; Likeliness

\section{Introduction}

Karl Landsteiner discovered ABO blood type in 1901. Gene of $\mathrm{ABO}$ is located on chromosome 9. Our blood group depends on what we have inherited from our parents. Due to the presence or absence of antigens and antibodies, there are different types of human blood groups. Antigens are on the surface of RBCs and antibodies are in the plasma of blood. According to the $\mathrm{ABO}$ blood typing system, there are four different kinds of blood types namely $\mathrm{A}, \mathrm{B}, \mathrm{AB}$ or $\mathrm{O}$. Blood group $\mathrm{A}$ has antigen $A$ and antibody $B$ while blood group $B$ has antigen $\mathrm{B}$ and antibody $\mathrm{A}$. Blood group $\mathrm{AB}$ has both antigen $\mathrm{A}$ and $B$ and no $A$ or $B$ antibodies while blood group 0 has neither A nor B antigens but have both $A$ and $B$ antibodies. 0 blood group people are "universal donors" and $A B$ blood group people are "universal receivers"[1].

$\mathrm{Rh}$ blood group system is the second type in human blood transfusion, encoded by three genes $\mathrm{C}, \mathrm{D}$ and $\mathrm{E}$. The
RBCs in $\mathrm{Rh}$ system contain another antigen called $\mathrm{RhD}$ antigen, which may be positive or negative. If it is present then blood group will be positive but if it is absent then blood group will be negative. Hence, there will be eight blood groups such as $\mathrm{A}+, \mathrm{A}-, \mathrm{B}+, \mathrm{B}-, \mathrm{AB}+, \mathrm{AB}-, \mathrm{O}+$ and $\mathrm{O}-$ [2].

Okra called as lady finger is a flowering plant. It has green seed pod. It is present in West African and South Asia. These species grow to around $2 \mathrm{~m}$ tall. The leaves are 10 to $20 \mathrm{~cm}$ long and broad. The diameters of flowers are 4 to $5 \mathrm{~cm}$, with 5 white yellow petals on which spots are present. The fruit is a capsule which is $18 \mathrm{~cm}$ long in length. It is a fibrous fruit.

Okra is a new food having many benefits. So, try eating healthy portion of okra as regular vegetable which is rich in organic fruit. In okra vitamins $A, B$, and $C$ are present in abundant amount. Also, some traces of zinc and calcium are present which make the okra plant as ideal 
vegetable to eat during pregnancy period. It is actually a supplement of fiber and folic acid.

Objective of the present study was to correlate blood grouping with lady finger likeliness.

\section{Materials and Method}

\section{Blood Grouping}

We placed kit in front of us. We pricked our upper portion of finger with the picker and squeeze the finger until we got a big drop of blood. We made three spots of blood in considerable amount on a slide. We added a small drop of antiserum A, antiserum B and antiserum D. We mixed antiserum and blood with the picker (needle) so that they mix well. After few seconds, we observed in which blood sample agglutination take place. If agglutination took place in that sample in which we added antiserum A then the blood group of that sample will be A. Then we checked agglutination in that sample in which we added antiserum $D$, if agglutination takes place in that sample then the blood group will be A positive, if does not then the blood group will be A negative. Antiserum D drop shows the positivity or negativity of that blood. If agglutination takes place in B not in A then blood group will be $B$ and also in $D$ then will be $B$ positive, if not then $B$ negative. Or agglutination in both $A$ and $B$ but not in $D$ then blood group will be $\mathrm{AB}$ negative, but if also in $\mathrm{D}$ then blood group will be $\mathrm{AB}$ positive. But if agglutination occurs in neither A nor $B$ then blood group will be 0 . Then came towards the $\mathrm{D}$, if agglutination takes place in $\mathrm{D}$ then blood group of that person will be 0 positive and vice versa.

\section{Project Designing}

During the sampling of subject, we asked them a question about our projects that are they like lady finger or not? Total of 173 subjects were participated in the project study who were students in Bahauddin Zakariya University, Multan, Pakistan.

\section{Statistical Analysis}

Statistical analysis was performed by using MS Excel.

\section{Result and Discussion}

What is the connection of blood group with lady finger likeliness?. Lady finger likeliness with respect to blood group given in Table 1.

\begin{tabular}{|c|c|c|c|c|}
\hline & Yes & Yes & No & No \\
\hline Blood group & Male & Female & Male & Female \\
\hline $\mathrm{A}+$ & $3.5 \%$ & $9.8 \%$ & $3.5 \%$ & $0 \%$ \\
\hline $\mathrm{A}-$ & $0.6 \%$ & $0.6 \%$ & $0 \%$ & $0 \%$ \\
\hline $\mathrm{B}+$ & $4.0 \%$ & $21.4 \%$ & $1.7 \%$ & $0.6 \%$ \\
\hline $\mathrm{B}-$ & $1.2 \%$ & $1.2 \%$ & $0 \%$ & $1.7 \%$ \\
\hline $\mathrm{AB}+$ & $1.7 \%$ & $2.9 \%$ & $0 \%$ & $0 \%$ \\
\hline $\mathrm{O}+$ & $0 \%$ & $0.6 \%$ & $0 \%$ & $4.6 \%$ \\
\hline $\mathrm{O}-$ & $7.5 \%$ & $16.8 \%$ & $2.3 \%$ & $1.7 \%$ \\
\hline
\end{tabular}

Table 1: The connection of blood grouping with lady finger likeliness.

Questionnaire based studies have given an important advancement in recent researches [3-10]. There is no research on connection of blood group with lady finger likeliness in the world.

\section{Conclusion}

It is concluded from the present study that B+ female like the lady finger most and $\mathrm{AB}$ - female like the lady finger least.

Blood group (1)

$\mathrm{Rh}(2)$

\section{Discussion}

Questionnaire based studies have been given important outcomes in current researches [3-10].

\section{References}

1. Qadir MI, Malik SA (2010) Comparison of alterations in red blood cell count and alterations in hemoglobin concentration in patients suffering from rectal carcinoma undergoing 5-fluorouracil and folic acid therapy. Pharmacology online Nl 3: 240-243. 
2. Qadir MI, Noor A (2018) Anemias. Rare \& Uncommon Diseases. Cambridge Scholars Publishing. Newcastle, England.

3. Qadir MI, Javid A (2018) Awareness about Crohn's Disease in biotechnology students. Glo Adv Res J Med Medical Sci 7(3): 062-064.

4. Qadir MI, Saleem A (2018) Awareness about ischemic heart disease in university biotechnology students. Glo Adv Res J Med Medical Sci 7(3): 059-061.

5. Qadir MI, Ishfaq S (2018) Awareness about hypertension in biology students. Int J Mod Pharma Res 7(2): 08-10.

6. Qadir MI, Mehwish (2018) Awareness about psoriasis disease. Int J Mod Pharma Res 7(2): 17-18.
7. Qadir MI, Shahzad R (2018) Awareness about obesity in postgraduate students of biotechnology. Int J Mod Pharma Res 7(2): 14-16.

8. Qadir MI, Rizvi M (2018) Awareness about thalassemia in post graduate students. MOJ Immunol 6(5): 163-165.

9. Qadir MI, Ghalia BA (2018) Awareness survey about colorectal cancer in students of M. Phil Biotechnology at Bahauddin Zakariya University, Multan, Pakistan. Nov Appro in Can Study 1(3).

10. Qadir MI, Saba G (2018) Awareness about intestinal cancer in university student. Nov Appro in Can Study $1(3)$. 